\title{
High Physical Self-Concept Benefits on School Adjustment of Korean Student-Athletes
}

\author{
Young-Jae Kim ${ }^{1}$, Jin-Hoon Jang ${ }^{2}$ and Jeong-Hyung Cho ${ }^{1, *}$ \\ 1 Department of Physical Education of Chung-Ang University, Seoul 06974, Korea; yjkim@cau.ac.kr \\ 2 Sanghyun Middle School, Seoul 06974, Korea; hoon8775@sen.go.kr \\ * Correspondence: cheer1007@naver.com; Tel.: +82-2-820-5386
}

Received: 28 February 2020; Accepted: 10 April 2020; Published: 13 April 2020

\begin{abstract}
Successful adjustment of student-athletes to their school is an internationally relevant issue. In Korea, school-athletes abandon their athletic activity at a rate of over $40 \%$, suggesting an urgent need to develop measures that allow them to balance sports and academic life. Therefore, this study aimed to investigate the effect of physical self-concept on school adaptation among student-athletes. We analyzed data from 589 student-athletes, including sex and award-winning career as covariates. Then, reliability and validity of scales were obtained. The results showed that student-athletes with higher physical self-concept are more likely to be successful in school adjustment. The effects of physical self-concept on school adjustment were proven to be mediated by sex and award-winning career of student-athletes. This result provides the basis for the importance of recognizing the concept of physical self as a way for student athletes to adapt well to school life. As differences depending on gender and award experience exist, they should be taken into account when teaching student athletes.
\end{abstract}

Keywords: school life; self-concept; youth; athletes

\section{Introduction}

Properly maintaining and adjusting to school life is very important during adolescence [1-4]. The World Health Organization (WHO) recommends daily physical activity for more than $60 \mathrm{~min}$ for teens aged 15 to 17 . This is because teenagers' participation in physical activities will help them adapt to school life [5]. However, student-athletes have adjustment difficulties when their activities exceed the WHO-recommended amount [6,7]. Among Korean students, the general dropout rate is less than $1 \%$, but when considering only student-athletes, over $40 \%$ abandon athletic activities before graduation. When including those who do not enter professional sports post-graduation, the abandonment rate reaches nearly $90 \%$ [8]. These student-athletes also cannot adjust to school life, resulting in $>50 \%$ transference rate and $11 \%$ dropout rate. Furthermore, over half $(51.6 \%)$ the students stop sports without any external extenuating circumstances [9]. Student-athletes may have more difficulty in adjusting because of several intrinsic characteristics that should be considered when developing assistance programs [10]. As the curriculum in Korea consists of 6 years of elementary school, 3 years of junior high school, and 3 years of high school, it is necessary to adapt to the new environment whenever the class changes. Student athletes in particular have less time to socialize with their classmates due to the inclusion of morning training programs before the first class, after-school training programs, and special training during the competition season. Psychological factors affect girls more than boys [11], while sex-based physical differences also influence adjustment capacity [12]. Additionally, student-athlete success is highly dependent on sporting achievements, and excellent performance in competitions [13] and winning awards increases their likelihood of pursuing a sporting career post-graduation [14]. Taken together, these findings indicate that gender and career awards won should be considered when investigating student-athlete adjustment to school. 
Only one study is available on Korean student-athletes [15], but it has a major limitation because participation guarantees the right to study. Therefore, voluntary compensation factors such as academic achievement are not considered despite being an important psychological factor affecting school adjustment [16]. Psychological factors are more effective than behavioral factors at inducing school adjustment [17] and, therefore, should be considered for student-athletes.

High self-concept (positive collection of beliefs about oneself) is linked to better academic and social achievement [18] because it is a variable that affects mental state, psychological well-being, and behavior in adolescents $[4,19]$. Psychological variables are based on self-assessment. A person with a high self-concept is highly accomplished in academic or social life [20]. Research has found that self-concepts are important factors in school life that affect mental state, psychological well-being, and human behavior [21]. However, the measurement factor of the existing self-concept was developed for general students, so it is difficult to apply it to student athletes who have a different culture from general students [22,23]. Therefore, it is necessary to identify and apply physical self-concept factors appropriate to the characteristics of student athletes. This is because athletes have a better understanding of the body than others to achieve the best performance [23]. Another caveat to consider is that due to differences in curriculum and school life culture, self-concept scales developed in other countries may not transfer to Korea, [24]. Therefore, in this study, we intend to examine the effect of physical self-concept criteria, which has been validated in Korea, on students' adjustment to school life according to the characteristics of students (gender and award experience).

\section{Materials and Methods}

\subsection{Participants}

This cross-sectional study involved 633 student-athletes (ages 13-18) in Seoul, attending 10 middle and high schools that are part of Korea's compulsory educational system. All participants were informed via written communication, and parents and legal guardians provided informed consent for student participation. Participants were recruited using the convenience sampling method, and only voluntary participants were enrolled. The final analysis included 589 valid samples after excluding 44 questionnaires with incomplete answers or missing data.

\subsection{Measurement}

\subsubsection{Physical Self-Concept}

Data were collected using the physical self-concept (PSC) questionnaire [23], adjusted for Korean adolescents from an original developed for English-speaking students [25]. This measurement tool consists of perceived sports ability (SCO) that is part of physical ability, health promotion (HP) that recognizes health state through physical activity and physical activity (PA) that recognizes the body through physical activity. This means that the higher the score, the higher the recognition of your body.

\subsubsection{School Adjustment}

Data were collected using a 23-item questionnaire [1] adjusted for Korean students from an English-language original. This measurement tool consists measurements of a teacher-to-student relationship (TRE), a relationship with schoolmates (SRE), an adaptation to school class (SCL), and an adherence to school rules (SRU) to measure performance. This means that the higher the score, the better you are adjusting to school life.

\subsection{Data Analysis}

In order to achieve the purpose of this study, the collected data was subjected to statistical analysis using the SPSS program version 25 through the coding process and data cleaning process. The demographic characteristics of the study subjects were analyzed by descriptive analysis and 
frequency analysis. In order to verify the reliability and validity of the measurement tools, Cronbach's $\alpha$, exploratory factor analysis (EFA), and confirmatory factor analysis (CFA) were conducted. Lastly, correlation analysis and multiple regression analysis were conducted to investigate the effects of physical self-concept on school life adaptation. The independent variables were SCO, PA, and HP, while the dependent variables were SCL, TRE, SRE, and SRU (Figure 1).

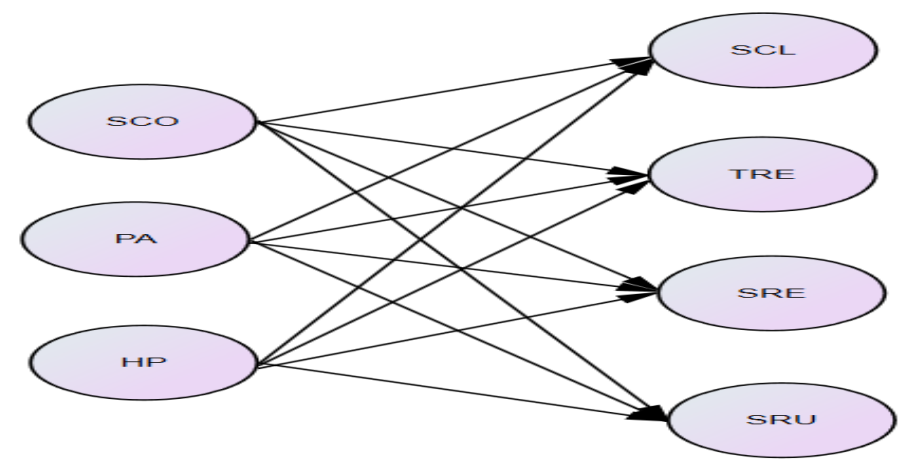

Figure 1. Variables in multiple regression. Independent variables: sports competence (SCO), physical activity (PA), health promotion (HP); dependent variables: school class (SCL), teacher relationship (TRE), schoolmate relationship (SRE), school rules (SRU).

\section{Results}

Table 1 shows the results of the factorial analysis to confirm the validity of physical self-concept. Participants responded using a five-point Likert scale (" $1=$ Not at all" to " $5=$ Very true"). A high total score indicates high physical self-concept. The questionnaire was both reliable and valid (SCO, $\alpha=0.873$; HP, $\alpha=0.846, \mathrm{PA}, \alpha=0.850$ ). Table 1 . In addition, feasibility has been ensured through exploratory factor analysis and verbatim factor analysis, all of which exceed the standard values.

Table 1. Results of Exploratory and Confirmatory Factor Analyses (EFA, CFA) for Physical Self-Concept.

\begin{tabular}{|c|c|c|c|c|c|c|}
\hline \multirow{2}{*}{ Items } & \multicolumn{3}{|c|}{ EFA } & \multicolumn{3}{|c|}{ CFA } \\
\hline & $1^{1}$ & $2^{2}$ & $3^{3}$ & 1 & 2 & 3 \\
\hline $\mathrm{SCO} 2$ & 0.817 & & & 0.778 & & \\
\hline $\mathrm{SCO} 1$ & 0.797 & & & 0.740 & & \\
\hline $\mathrm{SCO} 3$ & 0.763 & & & 0.701 & & \\
\hline $\mathrm{SCO} 4$ & 0.740 & & & 0.839 & & \\
\hline $\mathrm{SCO} 5$ & 0.634 & & & 0.739 & & \\
\hline PA 3 & & 0.791 & & & 0.749 & \\
\hline PA 1 & & 0.782 & & & 0.778 & \\
\hline PA 4 & & 0.756 & & & 0.721 & \\
\hline PA 2 & & 0.700 & & & 0.747 & \\
\hline PA 5 & & 0.576 & & & 0.654 & \\
\hline HP 2 & & & 0.882 & & & 0.576 \\
\hline HP 3 & & & 0.736 & & & 0.875 \\
\hline Cronbach's $\alpha$ & 0.873 & 0.846 & 0.850 & & $\mathrm{NFI}=0$ & \\
\hline Eigenvalue & 5.786 & 1.265 & 1.014 & & $\mathrm{TLI}=0$. & \\
\hline Variance $(\%)$ & 48.217 & 10.538 & 8.452 & & $\mathrm{CFI}=0$ & \\
\hline Variance accumulated (\%) & 48.217 & 58.755 & 67.208 & & $\mathrm{RMR}=0$ & \\
\hline \multicolumn{4}{|c|}{$\mathrm{KMO}=0.904, \chi^{2}=3421.509, \mathrm{df}=66, p<0.001$} & \multicolumn{3}{|c|}{$\mathrm{CMIN}=275.517, \mathrm{DF}=51, p<0.000$} \\
\hline
\end{tabular}

Table 2 shows the results of the factorial analysis to confirm the validity of School Adjustment Scale. Participants responded using a five-point Likert scale (" $1=$ Not at all" to " $5=$ very true"). A high 
score indicates better school life adjustment. The questionnaire was reliable and valid (TRE, $\alpha=0.806$; SRE, $\alpha=0.792$, SCL, $\alpha=0.839$, SRU, $\alpha=0.872$ ). Table 2. In addition, both exploratory and ascertained factors analysis have met the model adequacy values.

Table 2. Results of Exploratory and Confirmatory Factor Analysis for School Adjustment Scale.

\begin{tabular}{|c|c|c|c|c|c|c|c|c|}
\hline \multirow{2}{*}{ Items } & \multicolumn{4}{|c|}{ Exploratory Factor Analysis } & \multicolumn{4}{|c|}{ Confirmatory Factor Analysis } \\
\hline & $1^{1}$ & $2^{2}$ & $3^{3}$ & $4^{4}$ & 1 & 2 & 3 & 4 \\
\hline SCL 4 & 0.839 & & & & 0.851 & & & \\
\hline SCL 2 & 0.780 & & & & 0.772 & & & \\
\hline SCL 5 & 0.722 & & & & 0.712 & & & \\
\hline SCL 6 & 0.690 & & & & 0.750 & & & \\
\hline SCL 1 & 0.681 & & & & 0.777 & & & \\
\hline SCL 3 & 0.635 & & & & 0.588 & & & \\
\hline TRE 4 & & 0.742 & & & & 0.741 & & \\
\hline TRE 5 & & 0.723 & & & & 0.808 & & \\
\hline TRE 3 & & 0.722 & & & & 0.752 & & \\
\hline TRE 6 & & 0.712 & & & & 0.732 & & \\
\hline TRE 1 & & 0.635 & & & & 0.690 & & \\
\hline TRE 2 & & 0.556 & & & & 0.435 & & \\
\hline SRE 4 & & & 0.788 & & & & 0.792 & \\
\hline SRE 2 & & & 0.769 & & & & 0.835 & \\
\hline SRE 1 & & & 0.709 & & & & 0.748 & \\
\hline SRE 5 & & & 0.678 & & & & 0.606 & \\
\hline SRE 3 & & & 0.623 & & & & 0.479 & \\
\hline SRU 3 & & & & 0.702 & & & & 0.758 \\
\hline SRU 7 & & & & 0.689 & & & & 0.743 \\
\hline SRU 4 & & & & 0.689 & & & & 0.791 \\
\hline SRU 2 & & & & 0.611 & & & & 0.673 \\
\hline SRU 6 & & & & 0.610 & & & & 0.721 \\
\hline SRU 1 & & & & 0.605 & & & & 0.596 \\
\hline Cronbach's $\alpha$ & 0.839 & 0.806 & 0.792 & 0.872 & & NFI & & \\
\hline Eigen value & 8.291 & 2.120 & 1.812 & 1.445 & & TLI & & \\
\hline Variance $(\%)$ & 36.049 & 9.220 & 7.876 & 6.284 & & CFI & & \\
\hline Variance accumulated (\%) & 36.049 & 45.269 & 53.145 & 59.429 & & RMR & 039 & \\
\hline \multicolumn{5}{|c|}{$\mathrm{KMO}=0.920, \chi^{2}=6480.524, \mathrm{df}=253, p<0.001$} & \multicolumn{4}{|c|}{$\mathrm{CMIN}=838.429, \mathrm{DF}=224, p<0.000$} \\
\hline
\end{tabular}

The demographic characteristics of this study are as follows. Male participants ( $n=372 ; 63.2 \%$ ) outnumbered the female participants $(n=217 ; 36.8 \%) 155$ men participated, 1.3 times more than women. Additionally, 47\% (278) were middle school students and 52.8\% (311) were high school students (Table 3). More student-athletes did not win awards in their career $(n=329 ; 55.9 \%)$ than those who did $(n=260 ; 44.1 \%)$. For physical self-concept, students scored highest on PA (M = 4.36, SD = $0.618)$, then $\mathrm{HP}(\mathrm{M}=4.06, \mathrm{SD}=0.686)$, and finally $\mathrm{SCO}(\mathrm{M}=3.84$, $\mathrm{SD}=0.727)$. For school adjustment, they scored highest on SRE $(\mathrm{M}=4.00, \mathrm{SD}=0.553)$ and lowest on SRU $(\mathrm{M}=3.56)$.

Table 4 shows the average score of school adaptation according to the concept of physical self, and there found a statistically significant difference. Student athletes who best adapted to school classes were those with high physical activity $(\mathrm{M}=3.64, \mathrm{SD}=0.403 ; \mathrm{F}=9.049, p=0.001)$. Student athletes with the best relationship with teachers were those with a high level of perception on health promotion $(\mathrm{M}=6.37, \mathrm{SD}=0.325 ; \mathrm{F}=19.636, p=0.001)$. Students with good friendship with schoolmates were also the groups with high levels of awareness of health promotion $(\mathrm{M}=6.04, \mathrm{SD}=0.353 ; \mathrm{F}=17.130$, $p=0.001)$. Finally, the group that adheres well to school rules was found to have a higher awareness of health promotion $(\mathrm{M}=3.84, \mathrm{SD}=0.269 ; \mathrm{F}=14.252, p=0.001)$. 
Table 3. Demographic Characteristics and Questionnaire Scores by Variables $(n=589)$.

\begin{tabular}{|c|c|c|c|c|}
\hline Variable & $\mathbf{N}$ & $\%$ & Variable & Mean (SD) \\
\hline \multicolumn{2}{|c|}{ Sex } & & \multicolumn{2}{|c|}{ Physical self-concept } \\
\hline Male & 372 & $63.2 \%$ & SCO & $3.84(.727)$ \\
\hline Female & 217 & $36.8 \%$ & $\mathrm{HP}$ & $4.06(0.686)$ \\
\hline School & & & PA & $4.36(0.618)$ \\
\hline Middle & 278 & $47.2 \%$ & \multicolumn{2}{|c|}{ School adjustment } \\
\hline High & 311 & $52.8 \%$ & SCL & $3.93(0.621)$ \\
\hline \multicolumn{3}{|c|}{ Award-winning career } & TRE & $3.99(0.641)$ \\
\hline Yes & 260 & $44.1 \%$ & SRE & $4.00(0.553)$ \\
\hline No & 329 & $55.9 \%$ & SRU & $3.56(0.705)$ \\
\hline
\end{tabular}

Table 4. Comparison of Mean between Physical Self-Content and School Adjustment.

\begin{tabular}{cccccc}
\hline $\begin{array}{c}\text { Independent } \\
\text { Variable }\end{array}$ & $\begin{array}{c}\text { Dependent } \\
\text { Variable }\end{array}$ & $\begin{array}{c}\text { Mean } \\
\text { Square }\end{array}$ & $\begin{array}{c}\text { Standard } \\
\text { Variation }\end{array}$ & F & Significance \\
\hline \multirow{2}{*}{ SCO $^{1}$} & SCL $^{4}$ & 3.21 & 0.411 & 7.813 & 0.001 \\
& TRE $^{5}$ & 3.67 & 0.283 & 12.988 & 0.001 \\
& SRE $^{6}$ & 2.84 & 0.335 & 8.489 & 0.001 \\
& SRU $^{7}$ & 2.09 & 0.249 & 8.391 & 0.001 \\
\hline \multirow{3}{*}{$\mathrm{HP}^{2}$} & $\mathrm{SCL}^{4}$ & 2.74 & 0.474 & 5.790 & 0.001 \\
& $\mathrm{TRE}^{5}$ & 6.37 & 0.325 & 19.636 & 0.001 \\
& $\mathrm{SRE}^{6}$ & 6.04 & 0.353 & 17.130 & 0.001 \\
& $\mathrm{SRU}^{7}$ & 3.84 & 0.269 & 14.252 & 0.001 \\
\hline $\mathrm{PA}^{3}$ & $\mathrm{SCL}^{4}$ & 3.64 & 0.403 & 9.049 & 0.001 \\
& $\mathrm{TRE}^{5}$ & 3.50 & 0.294 & 11.946 & 0.001 \\
& $\mathrm{SRE}^{6}$ & 3.01 & 0.334 & 9.051 & 0.001 \\
& $\mathrm{SRU}^{7}$ & 2.33 & 0.246 & 9.503 & 0.001 \\
\hline
\end{tabular}

${ }^{1}$ Sports Competence (SCO), ${ }^{2}$ Health Promotion (HP), ${ }^{3}$ Physical Activity (PA), ${ }^{4}$ School Class (SCL), ${ }^{5}$ Teacher Relationship (TRE), ${ }^{6}$ Schoolmates Relationship (SRE), ${ }^{7}$ School Rules (SRU).

Table 5 shows the correlation between factors. All physical self-concept and school adjustment variables positively correlated, with the strongest relationship being between $\mathrm{SCO}$ and $\mathrm{PA}(\mathrm{r}=0.643$, $p<0.001)$ and the weakest, between HP and SCL $(r=0.224, p<0.001)$. Multicollinearity was not an issue because no correlation coefficients were over 0.800 .

Table 5. Comparison of Means between Physical Self-Content and School Adjustment.

\begin{tabular}{|c|c|c|c|c|c|c|c|}
\hline Independent Variable & 1 & 2 & 3 & 4 & 5 & 6 & 7 \\
\hline 1. $\mathrm{SCO}^{1}$ & 1 & & & & & & \\
\hline 2. $\mathrm{HP}^{2}$ & $0.423^{* * *}$ & 1 & & & & & \\
\hline 3. $\mathrm{PA}^{3}$ & $0.643^{* * *}$ & $0.499^{* * *}$ & 1 & & & & \\
\hline 4. $\mathrm{SCL}^{4}$ & $0.432 * * *$ & $0.224^{* * *}$ & $0.421 * * *$ & 1 & & & \\
\hline 5. $\mathrm{TRE}^{5}$ & $0.525^{* * *}$ & $0.407^{* * *}$ & $0.488^{* * *}$ & $0.531^{* * *}$ & 1 & & \\
\hline 6. SRE 6 & $0.427^{* * *}$ & $0.377^{* * *}$ & $0.413^{* * *}$ & $0.416^{* * *}$ & $0.500 * * *$ & 1 & \\
\hline 7. SRU ${ }^{7}$ & $0.400^{* * *}$ & $0.350^{* * *}$ & $0.436^{* * *}$ & $0.483^{* * *}$ & $0.496^{* * *}$ & $0.368^{* * *}$ & 1 \\
\hline \multicolumn{8}{|c|}{$* * * p<0.001$} \\
\hline
\end{tabular}

${ }^{1}$ Sports Competence (SCO), ${ }^{2}$ Health Promotion (HP), ${ }^{3}$ Physical Activity (PA), ${ }^{4}$ School Class (SCL), ${ }^{5}$ Teacher Relationship (TRE), ${ }^{6}$ Schoolmates Relationship (SRE), ${ }^{7}$ School Rules (SRU).

Linear regression revealed that among girls, higher SCL corresponds to SCO $(\beta=0.296, p<0.001)$, while higher SCL corresponds to HP $(\beta=0.233, p<0.001)$, and higher TRE corresponds to PA ( $\beta=$ $0.282, p<0.001)$ respectively. Among boys, higher TRE corresponds to SCO $(\beta=0.366, p<0.001)$, 
while higher SCL corresponds to PH ( $\beta=0.264, p<0.001)$, and higher SRE corresponds to PA ( $\beta=$ $0.128, p<0.001$ ) respectively (Table 6 ). Figure 2 shows the effect of physical self-concepts on school adaptation based on sex.

Table 6. Linear Regression of Physical Self-Concept and School Adjustment According to Sex (n= 589).

\begin{tabular}{cccccccc}
\hline \multirow{2}{*}{$\begin{array}{c}\text { Dependent } \\
\text { Variable }\end{array}$} & \multirow{2}{*}{$\begin{array}{c}\text { Independent } \\
\text { Variable }\end{array}$} & \multicolumn{3}{c}{ Male } & \multicolumn{3}{c}{ Female } \\
\cline { 3 - 8 } & $\mathrm{SCO}^{1}$ & 0.266 & 0.059 & 0.000 & 0.296 & 0.079 & 0.000 \\
$\mathrm{SCL}^{4}$ & $\mathrm{HP}^{2}$ & 0.264 & 0.071 & 0.000 & 0.233 & 0.078 & 0.005 \\
& $\mathrm{PA}^{3}$ & -0.041 & 0.064 & 0.464 & 0.004 & 0.077 & 0.959 \\
\hline \multirow{2}{*}{ TRE $^{5}$} & $\mathrm{SCO}^{1}$ & 0.366 & 0.046 & 0.000 & 0.243 & 0.067 & 0.001 \\
& $\mathrm{HP}^{2}$ & 0.207 & 0.056 & 0.001 & 0.208 & 0.066 & 0.006 \\
& $\mathrm{PA}^{3}$ & 0.100 & 0.050 & 0.051 & 0.282 & 0.065 & 0.000 \\
\hline \multirow{3}{*}{$\mathrm{SRE}^{6}$} & $\mathrm{SCO}^{1}$ & 0.267 & 0.051 & 0.000 & 0.179 & 0.074 & 0.031 \\
& $\mathrm{HP}^{2}$ & 0.215 & 0.062 & 0.001 & 0.129 & 0.073 & 0.116 \\
& $\mathrm{PA}^{3}$ & 0.128 & 0.056 & 0.017 & 0.278 & 0.072 & 0.000 \\
\hline \multirow{2}{*}{$\mathrm{SRU}^{7}$} & $\mathrm{SCO}^{1}$ & 0.176 & 0.044 & 0.003 & 0.145 & 0.066 & 0.077 \\
& $\mathrm{HP}^{2}$ & 0.235 & 0.053 & 0.000 & 0.230 & 0.065 & 0.005 \\
& $\mathrm{PA}^{3}$ & 0.124 & 0.048 & 0.027 & 0.230 & 0.064 & 0.001 \\
\hline
\end{tabular}

${ }^{1}$ Sports Competence (SCO), ${ }^{2}$ Health Promotion (HP), ${ }^{3}$ Physical Activity (PA), ${ }^{4}$ School Class (SCL), ${ }^{5}$ Teacher Relationship (TRE), ${ }^{6}$ Schoolmates Relationship (SRE), ${ }^{7}$ School Rules (SRU).

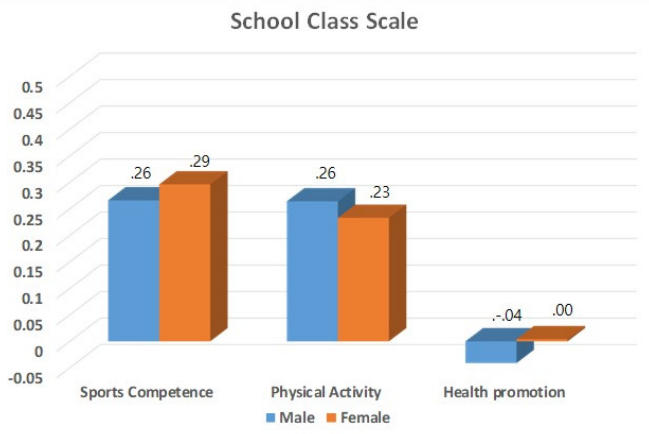

(a)

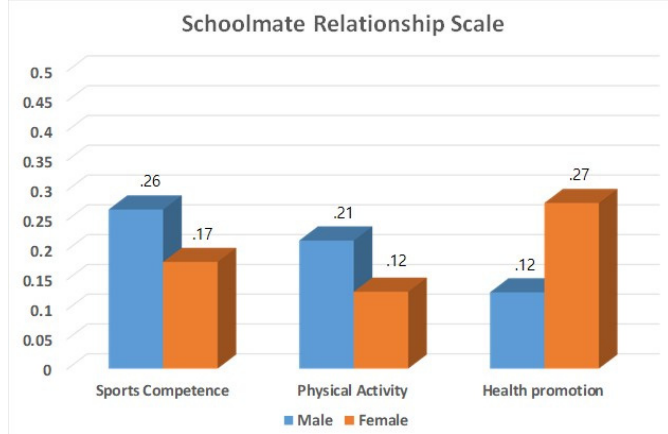

(c)

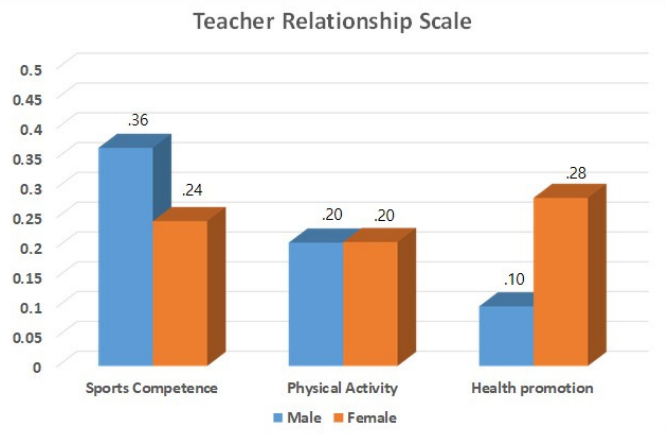

(b)

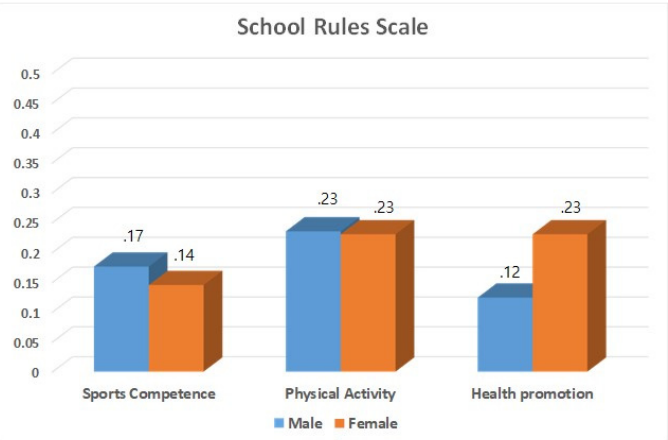

(d)

Figure 2. Effect of physical self-concept on school adjustment by gender: (a) school class differences,

(b) teacher relationship differences, (c) schoolmate relationship differences, (d) school rules differences.

Among students with an award-winning career, higher TRE corresponds to SCO $(\beta=0.352$, $p<0.001)$, while higher SCL corresponds to HP $(\beta=0.262, p<0.001)$, and higher SRE corresponds to PA ( $\beta=0.243, p<0.001)$ respectively. Among those who did not win awards, higher TRE corresponds to SCO $(\beta=0.267, p<0.001)$, while higher TRE corresponds to HP $(\beta=0.299, p<0.001)$, and higher 
TRE corresponds to PA $(\beta=0.165, p<0.001$ ) respectively (Table 7). Figure 3 shows the effect of physical self-concepts on school adaptation based on award-winning career.

Table 7. Linear Regression of Physical Self-Concept and School Adjustment According to Award $(n=589)$.

\begin{tabular}{cccccccc}
\hline \multirow{2}{*}{$\begin{array}{c}\text { Dependent } \\
\text { Variable }\end{array}$} & \multirow{2}{*}{$\begin{array}{c}\text { Independent } \\
\text { Variable }\end{array}$} & \multicolumn{2}{c}{ Granular Experience NO } & \multicolumn{2}{c}{ Granular Experience YES } \\
\cline { 3 - 8 } & & $\beta$-Coefficient a & SE & $p$ & $\beta$-Coefficient a & SE & $p$ \\
\hline \multirow{3}{*}{$\mathrm{SCL}^{4}$} & $\mathrm{SCO}^{1}$ & 0.256 & 0.069 & 0.001 & 0.273 & 0.065 & 0.000 \\
& $\mathrm{HP}^{2}$ & 0.267 & 0.083 & 0.001 & 0.262 & 0.066 & 0.000 \\
& $\mathrm{PA}^{3}$ & -0.050 & 0.075 & 0.462 & 0.001 & 0.064 & 0.988 \\
\hline \multirow{2}{*}{$\mathrm{TRE}^{5}$} & $\mathrm{SCO}^{1}$ & 0.267 & 0.055 & 0.000 & 0.352 & 0.053 & 0.000 \\
& $\mathrm{HP}^{2}$ & 0.299 & 0.067 & 0.000 & 0.128 & 0.054 & 0.041 \\
& $\mathrm{PA}^{3}$ & 0.165 & 0.060 & 0.006 & 0.166 & 0.053 & 0.002 \\
\hline \multirow{2}{*}{$\mathrm{SRE}^{6}$} & $\mathrm{SCO}^{1}$ & 0.254 & 0.062 & 0.001 & 0.212 & 0.058 & 0.001 \\
& $\mathrm{HP}^{2}$ & 0.185 & 0.075 & 0.022 & 0.163 & 0.060 & 0.011 \\
& $\mathrm{PA}^{3}$ & 0.128 & 0.067 & 0.055 & 0.243 & 0.058 & 0.000 \\
\hline \multirow{2}{*}{$\mathrm{SRU}^{7}$} & $\mathrm{SCO}^{1}$ & 0.179 & 0.056 & 0.018 & 0.167 & 0.049 & 0.008 \\
& $\mathrm{HP}^{2}$ & 0.285 & 0.068 & 0.001 & 0.229 & 0.050 & 0.000 \\
& $\mathrm{PA}^{3}$ & 0.073 & 0.061 & 0.281 & 0.213 & 0.048 & 0.000 \\
\hline
\end{tabular}

${ }^{1}$ Sports Competence (SCO), ${ }^{2}$ Health Promotion (HP), ${ }^{3}$ Physical Activity (PA), ${ }^{4}$ School Class (SCL), ${ }^{5}$ Teacher Relationship (TRE), ${ }^{6}$ Schoolmates Relationship (SRE), ${ }^{7}$ School Rules (SRU).

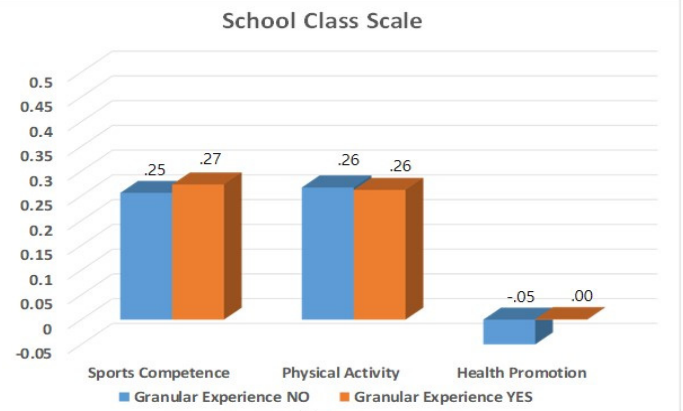

(a)

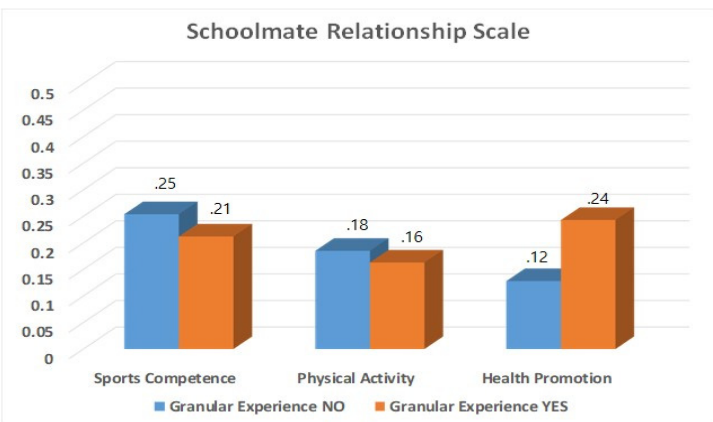

(c)

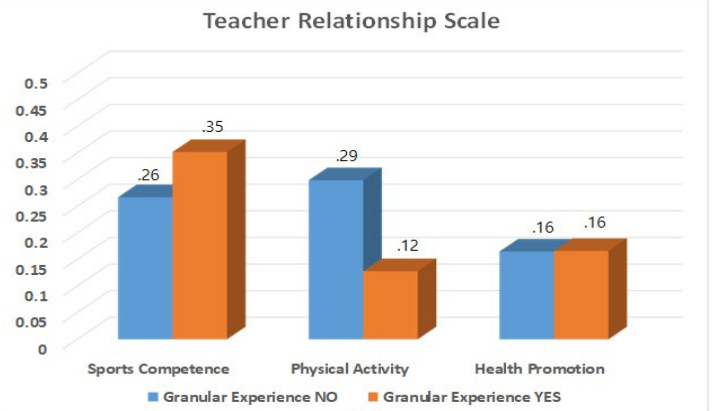

(b)

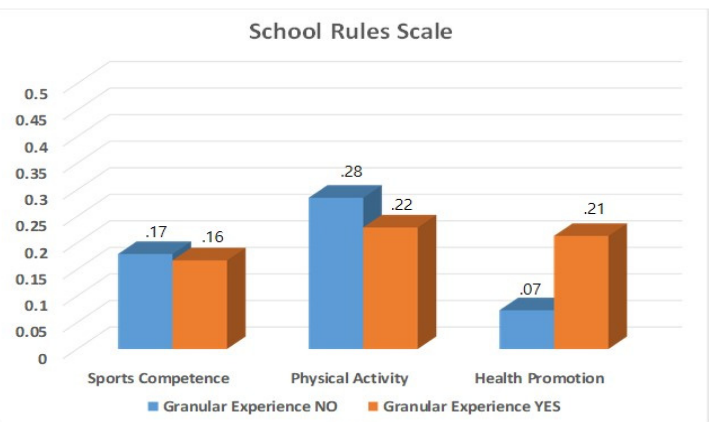

(d)

Figure 3. Effect of physical self-concept on school adjustment by award-winning career: (a) school class differences, (b) teacher relationship differences, (c) schoolmates relationship differences, (d) school rules differences.

\section{Discussion}

This study verified the effect of physical self-concept on the adaptation of school life in student athletes through gender and award experience. However, this sample was recruited by expedient sampling, so you should be careful about the dissection. 
Higher SCO is correlated with higher TRE. High-performing players have a good relationship with coaches and their parents. This is more evident in younger players [26,27]. Relationships with others are built on trust. In other words, because the goal of both players and coaches is to achieve good results, high-achieving student players have a lot of experience in winning, which gives them confidence in their coaches, which has the same effect on others who lead them [20]. Higher SCO was correlated with higher TRE, consistent with previous findings [28] indicating that life-skill coaching benefits sports participation. Similarly, another study demonstrated that student-athletes perform better when they communicate constantly with and seek direction from their managers [29]. Thus, we can conclude that a good relationship with coaches could allow student-athletes to form similar bonds with teachers, benefiting school life adjustment.

Analysis of the correlation between physical self-concept and school life adaptation showed that the high physical self-concept of student athletes had a positive effect on their school life adaptation. These results reflect that the higher the physical self-concept of student athletes, the better their adjustment to class and rules and their relationship with teachers and classmates [29]. In other words, because student athletes understand their body, psychological factors such as self-esteem and sense of achievement are high [28]. This study's finding regarding the effects of positive psychological factors is identical to that of a previous study [21] that such positive psychological factors had positive effects on school life.

Male student-athletes scored higher in TRE and SRU, whereas female athletes performed better in SCL and SRE. This gender difference may be based on endocrinological factors [30], with hormone secretion increasing under greater physical activity [31]. Regardless of the mechanism, we can conclude that boys are better at adjusting to rules and the regimented elements of school life, while girls are better at adjusting to classes and social relationships with their peers. This observation in female student-athletes corroborates results indicating that they have higher academic success [32]. However, this is coupled with lower athletic identity than boys, perhaps explaining why girls abandon sports at a 13.4\% higher rate than abandonment rates among boys [33].

Based on these results, we recommend that parents and other mentors highlight the excellent performance of student-athletes to the students themselves. Understanding their own achievement should lead to the formation of beneficial relationships with authority figures, including teachers. A previous study found that female student-athletes with higher HP scores are likely to have better peer relationships, similar to a study on health concerns of middle school girls [34]. Notably, female students are more likely to discuss physical health concerns such as menstruation with their friends than their parents or managers [35-37]. Therefore, it may be particularly important for female students to have opportunities for peer engagement on health matters, in addition to counseling with their managers. Here, we also demonstrated that PA and HP affected school adjustment among female student-athletes more than SCO, perhaps because parents of girls are more concerned about their children's well-being than higher performance [38].

Student-athletes who have not won awards exhibit a positive correlation between higher PA and most school-adjustment variables (excluding SRE). In contrast, among students who have won awards, higher SCO is associated with SCL and TRE. These results are consistent with previous research [39] showing that people tend to continue participating in activities that produce satisfactory outcomes. Through winning awards, the student-athletes consider themselves competent in sports, and this feeling of achievement appears to benefit their school adjustment. Therefore, we recommend encouraging appreciation of physical activity rather than sporting competence among students without award-winning experience, especially because steady exercise is rewarding even without a physical token of victory [40]. Our suggestion finds support in data showing that participation rates increase with greater awareness of physical activity's benefits [41]. Mentors of student-athletes should aim to increase successful school adjustment through providing emphasizing such benefits, rather than blaming students for lack of awards. 
Despite these encouraging findings, our study has several limitations. First, participants did it voluntarily, but a sample of convenience samples was used, and the participants were limited to secondary students. Future studies should therefore investigate the observed differences among elementary, secondary, and university student-athletes. Second, because student-athletes have varied motivations [42] that differentially influences burnout [43], we recommend that researchers examine such motivations for engaging in sports. Third, we only examined the potential mediating influence of two variables: sex and award-winning career. Future studies should also examine factors such as sporting-event types and player careers [44] to obtain a better understanding of factors that affect the academic achievement of student-athletes.

\section{Conclusions}

Analysis of the correlation between physical self-concept and school life adaptation showed that the high physical self-concept of student athletes had a positive effect on their school life adaptation. These results reflect that the higher the physical self-concept of student athletes, the better their adjustment to class and rules and their relationship with teachers and classmates [41]. In other words, because student athletes understand their body, psychological factors such as self-esteem and sense of achievement are high [42]. This study's finding regarding the effects of positive psychological factors is identical to that of a previous study [28] that such positive psychological factors had positive effects on school life. Our results confirmed that student-athletes with higher physical self-concept are more likely to be successful in school adjustment. In particular, while students of both genders were better adjusted when PA scores were high, boys had improved adjustment with higher SCO, and girls, with higher HP. Thus, coaches and other mentors of student-athletes should develop management plans that build confidence for sports in a gender-specific manner. In addition, we found that SCO had greater influence on adjustment for student-athletes with award-winning careers, while PA was more influential for those without awards. These outcomes indicate that coaches should emphasize factors such as PA among non-award-winning students to better encourage successful school adjustment.

Author Contributions: Conceptualization, Y.-J.K. and J.-H.J; Methodology, J.-H.C.; Validation, Y.-J.K., J.-H.J., and J.-H.C; Formal Analysis, J.-H.C.; Investigation, J.-H.J; Data Curation, J.-H.C. and Y.-J.K; Writing-Original Draft Preparation, J.-H.J.; Writing-Review and Editing, J.-H.J. and Y.-J.K. All authors have read and agreed to the published version of the manuscript.

Funding: This research received no external funding.

Conflicts of Interest: The authors declare no conflict of interest.

\section{References}

1. Brizuela, B.M.; García-Sellers, M.J. School adaptation: A triangular process. Am. Educ. Res. J. 1999, 36, 345-370. [CrossRef]

2. Shin, M.; Lee, C.; Lee, Y.; Shin, M.; Lee, C.; Lee, Y. Effect of aggression on peer acceptance among adolescents during school transition and non-transition: Focusing on the moderating effects of gender and physical education activities. Int. J. Environ. Res. Public Health 2019, 16, 3190. [CrossRef]

3. Emm-Collison, L.G.; Lewis, S.; Reid, T.; Matthews, J.; Sebire, S.J.; Thompson, J.L.; Salway, R.; Jago, R. Striking a balance: Physical activity, screen-viewing and homework during the transition to secondary school. Int. J. Environ. Res. Public Health 2019, 16, 3174. [CrossRef]

4. Sevil, J.; García-González, L.; Abós, Á.; Generelo Lanaspa, E.; Aibar Solana, A. Which school community agents influence adolescents' motivational outcomes and physical activity? Are more autonomy-supportive relationships necessarily better? Int. J. Environ. Res. Public Health 2018, 15, 1875. [CrossRef] [PubMed]

5. Padial-Ruz, R.; Pérez-Turpin, J.A.; Cepero-González, M.; Zurita, O.F. effects of physical self-concept, emotional isolation, and family functioning on attitudes towards physical education in adolescents: Structural equation analysis. Int. J. Environ. Res. Public Health 2019, 17, 94. [CrossRef] [PubMed] 
6. Challa, S.; Lakey, E.; Smith, K.; Holliday, M.; Vest, J.; Gattas, C.; Hunt, K. Assessing elite athletes using PROMIS tools: The STEALTH project (Student Athlete Health Assessment). Foot Ankle Orthop. 2019, 4, 4. [CrossRef]

7. Gilbert, K.C. Psychological Effects of Sport Injury on NCAA Division I Student Athlete: A Qualitative Case Study. Bachelor's Thesis, Honors College, Oregon State University, Corvallis, OR, USA, 22 May 2019.

8. Nam, D. A retired student-athletes “What Should I Do Right Now?”. Naver Sports 2018, 5, 18.

9. Kang, M.S. 251 high school athletic elite students in Kwnagju and Jeonnam abandon their activities in recent 3 years. Newsis 2018, 10, 28.

10. Priambodo, A.; Hariyanto, A.; Dinata, V.C.; Ristianto, K.O.; Prakoso, B.B. Learning need assessment: Formulating blended-learning as academic services for student-athletes. In Proceedings of the International Conference on Research and Academic Community Services, Universitas Negeri Surabaya, Indonesia, 7 September 2019; Volume 390, pp. 217-220.

11. McGannon, K.R.; Schinke, R.J.; Ge, Y.; Blodgett, A.T. Negotiating gender and sexuality: A qualitative study of elite women boxer intersecting identities and sport psychology implications. J. Appl. Sport Psychol. 2018, 31, 168-186. [CrossRef]

12. Ingrell, J.; Larneby, M.; Johnson, U.; Hedenborg, S. Student-athletes' beliefs about athletic ability: A longitudinal and mixed method gender study. Scand. Sport Stud. Forum 2019, 10, 117-138.

13. Hoffman, W.B. Developing an Evaluation Instrument to Predict Student Athlete Success. Bachelor's Thesis, Walden University, Minneapolis, MN, USA, 2014.

14. McCarthy, C. Gain insight into supporting student-athletes' transition to life after graduation. Stud. Aff. Today 2019, 22, 1-5. [CrossRef]

15. Kang, M.; You, B. Policy evaluation of school sports club through FGI: Value critical approach to 'The Player Studying, The Student Exercising'. Korean Athl. Policy Assoc. 2019, 17, 193-206.

16. Stocz, M.; Schlereth, N.; Crum, D.; Maestas, A.; Barnes, J. Student Athlete Compensation: An Alternative Compensation Model for All Athletes Competing in NCAA Athletics. J. High. Educ. Athl. Innov. 2019, 3, 82-101. [CrossRef]

17. Wang, H.; Zhou, X.; Lu, C.; Wu, J.; Deng, X.; Hong, L. Adolescent bullying involvement and psychosocial aspects of family and school life: A cross-sectional study from Guangdong Province in China. PLoS ONE 2012, 7, 1-10. [CrossRef] [PubMed]

18. Fernández-Bustos, J.G.; Infantes-Paniagua, A.; Cuevas, R.; Contreras, O.R. Effect of physical activity on self-concept: Theoretical model on the mediation of body image and physical self-concept in adolescents. Front. Psychol. 2019, 10, 1-11. [CrossRef]

19. Rosenverg, M. Self-concept and psychological well-being in adolescence. Dev Self. 1985, 1, 205-246.

20. OcGrady, C.; Dahm, M.R.; Roger, P.; Yates, L. Trust, talk and the dictaphone: Tracing the discursive accomplishment of trust in a surgical consultation. Discourse Soc. 2014, 25, 65. [CrossRef]

21. Lassen, S.R.; Steele, M.M.; Sailor, W. The relationship of school-wide Positive Behavior Support to academic achievement in an urban middle school. Psychol. Sch. 2006, 43, 701. [CrossRef]

22. Bishop, J.B.; Lacour, M.A.M.; Nutt, N.J.; Yamada, V.A.; Lee, J.Y. Reviewing a decade of change in the student culture. J. Coll. Stud. Psychother. 2004, 18, 3. [CrossRef]

23. Marsh, H.W.; Hey, J.; Roche, L.A.; Perry, C. Structure of physical self-concept: Elite athletes and physical education students. J. Educ. Psychol. 1997, 89, 369. [CrossRef]

24. Choi, S.I.; Jeong, C.H.; Kim, B.J. Development of the physical self-concept scale for the youth. Korean J. Sport Psychol. 2005, 16, 169-188.

25. Lee, K.A.; Shin, H.R.; Yu, N.H.; Lee, K.H. School counselling: Study on development of short-form university adjustment scale and validation. J. Couns. 2008, 9, 739-754.

26. Gould, D.; Carson, S. The relationship between perceived coaching behaviors and developmental benefits of high school sports participation. Hell. J. Psychol. 2010, 7, 298-314.

27. Jowett, S.; Cramer, D. The prediction of young athletes' physical self from perceptions of relationships with parents and coaches. Psychol. Sport Exerc. 2010, 11, 140. [CrossRef]

28. Chomitz, V.R.; Slining, M.M.; McGowan, R.J.; Mitchell, S.E.; Dawson, G.F.; Hacker, K.A. Is there a relationship between physical fitness and academic achievement? Positive results from public school children in the Northeastern United States. J. Sch. Health 2009, 79, 30. [CrossRef] 
29. Van, M.D.; Van, H.M. The quality of school life: Teacher-student trust relationships and the organizational school context. Soc. Indic. Res. 2010, 100, 85-100.

30. Paus, T.; Wong, A.P.; Syme, C.; Pausova, Z. Sex differences in the adolescent brain and body: Findings from the saguenay youth study. J. Neurosci. Res. 2016, 95, 362-370. [CrossRef]

31. Hackney, A.C.; McMurray, R.G.; Judelson, D.A.; Harrell, J.S. Relationship between Caloric Intake, body composition, and physical activity to leptin, thyroid hormones, and cortisol in adolescents. Jpn. J. Phychol. 2003, 53, 475-479. [CrossRef]

32. Lee, I.G.; Huh, C.H.; Ryu, T.H. The exploration on dropped causes of drop-out student athletes and ways of improving their problems. Korean J. Sport Sci. 2011, 22, 2189-2202.

33. Rankin, S.; Merson, D.; Sorgen, C.H.; McHale, I.; Loya, K.; Oseguera, L. Student-athlete climate study (SACS) final report. Cent. Study High. Educ. 2011, 6 .

34. Baek, D.; Choi, Y.; Lee, H. Universal welfare may be costly: Evidence from school meal programs and student fitness in South Korea. Sustainability 2019, 11, 1290. [CrossRef]

35. Rembeck, G.I.; Möller, M.; Gunnarsson, R.K. Attitudes and feelings towards menstruation and womanhood in girls at menarche. Acta Paediatr. 2007, 95, 707-714. [CrossRef]

36. You, S.; Shin, K. Body esteem among korean adolescent boys and girls. Sustainability 2019, 11, 2051. [CrossRef]

37. Wright, K.O. "You have endometriosis": Making menstruation-related pain legitimate in a biomedical world. Health Commun. 2019, 34, 912-915. [CrossRef] [PubMed]

38. Lee, S.H.; Kim, K.M. A study on the structural relationship between parenting attitude, school adaptation, self-efficiency and subjective well-being of elementary school students. Korean Assoc. Learn. Cent. Curric. Instr. 2019, 31, 19. [CrossRef]

39. Hu, S. Scholarship awards, college choice, and student engagement in college activities: A study of high-achieving low-income students of color. J. Coll. Stud. Dev. 2010, 51, 150-161. [CrossRef]

40. Sánchez-Miguel, P.A.; Leo, F.M.; Amado, A.D.; Hortigüela, A.D.; Tapia-Serrano, M.A.; De La Cruz-Sánchez, E. Children's physical self-concept and body image according to weight status and physical fitness. Sustainability 2020, 12, 782. [CrossRef]

41. Lee, Y.; Lim, S. Effects of sports activity on sustainable social environment and juvenile aggression. Sustainability 2019, 11, 2279. [CrossRef]

42. Holden, S.L.; Forester, B.E.; Williford, H.N.; Reilly, E. Sport locus of control and perceived stress among college student-athletes. Int. J. Environ. Res. Public Health 2019, 16, 2823. [CrossRef]

43. Peraita-Costa, I.; Llopis-Morales, A.; Marí-Bauset, S.; Marí-Sanchis, A.; Marí-Sanchis, S.; Morales-Suárez-Varela, M. Burnout syndrome risk in child and adolescent tennis players and the role of adherence to the Mediterranean diet. Int. J. Environ. Res. Public Health 2020, 17, 929. [CrossRef]

44. Yang, S.; Xu, J.; Yang, R. Research on coordination and driving factors of sports industry and regional sustainable development-Empirical research based on panel data of provinces and cities in eastern China. Sustainability 2020, 12, 813. [CrossRef]

(C) 2020 by the authors. Licensee MDPI, Basel, Switzerland. This article is an open access article distributed under the terms and conditions of the Creative Commons Attribution (CC BY) license (http://creativecommons.org/licenses/by/4.0/). 